\title{
PREFACE
}

$\mathrm{B}_{\mathrm{e}}$

etween I955 and 1970 federal funding in the United States for scientific research and development (R\&D) increased sixfold, from about $\$ 6$ billion to $\$ 36$ billion. ${ }^{1}$ This relatively rapid infusion of public funds primarily into university research centers, enlarging some and creating others, was accompanied by the emergence of a new academic specialty: science and technology policy studies. Given the importance of government influence on the nature and volume of scientific research being conducted during the first two decades of the Cold War, it is not surprising that the fields of political science and public administration would respond by laying the foundations of our appreciation of the dynamics and consequences of the interactions between public policy and research and development.

If there was a pioneer in the literature generated by the new inquiry into the interplay between science and politics, it was Don K. Price. Price-who would become dean of the Kennedy School of Government at Harvard University-had served as a trusted aide to James Webb, director of the Bureau of the Budget (BOB; to be renamed Office of Management and Budget in I970) during the creation of the National Science Foundation (NSF). In Price's Government and Science (1954) and The Scientific Estate (1965) he acquainted a new generation of readers and scholars with the fact that scientists had become one of the four "estates"-scientists, professionals, administrators, and politicianscompeting for power and influence in constitutional government in the United States. Scientists and other professionals, no less than administrators and politicians, when acting in political roles are not, nor can they be, guided by what their learning has taught them.

Price's Government and Science was followed in 1957 by A. Hunter Dupree's Science in the Federal Government: A History of Policies and Activities and, during the I96os, the publication of what have become classics in the literature of science and technology policy: Derek J. De Solla Price's Little Science, Big Science (I963), Daniel Greenberg's The Politics of Pure Science (1967), and Harvey Brooks's The Government of Science (1968). During the more than three decades that followed, political scientists, economists, historians, public and private 
research administrators, and scientists themselves have built on the foundations laid in the ig6os. In the process they have focused on special aspects of the science-technology-politics relationship: the roles of, and consequences for universities; the challenges of converting scientific findings to successful technologies; international comparisons of policies to promote research and development; and the economics of innovation, to name only a few. An overview of this rich literature, which provides a scholarly context for the following chapters, is the subject of the essay on sources following chapter Io.

From time to time, as we learn more and more about complex policy issues, it can be useful to step back and increase the angle of our lens, enabling us to appreciate anew the no less complex frames of reference in which those issues occur and will inevitably help to shape their outcome. Those complementary frames of reference will enable us to recognize the ongoing institutional, ideological, and legal traditions that may render policy issues seemingly intractable, and suggest new ways of resolving them or, if resolution seems unlikely, adapting to them. This widening of the angle of our lens, as we focus on the national policy challenges posed by advances in science and technology, has revealed in the background an idea, one that has animated much of modern history, including the history of science and technology: the concept of "open systems."

As the economist Robert B. Reich demonstrated in The Power of Public Ideas (1988), the instrumentalism that dominates the prevailing wisdom about politics neglects the comparably important role of ideas in shaping democratic deliberation about "what is good for society" and how best to achieve our common aspirations. ${ }^{2}$ The purpose of this book is to explore the ways in which a proclivity toward open systems-whether as an idea, an objective, or an approach toward the design of institutions and things-has shaped, and continues to shape, the relationships between science, technology, and policy in the United States.

It is impossible to have toiled with any success in the vineyards of policy development in our nation's capital without learning from others. Colleagues at the National Aeronautics and Space Administration, the National Science Foundation, and the White House Office of Science and Technology Policy especially sharpened my sense of the challenges and possibilities of influencing public policies to advance science and technology, while being sensitive to their social, political, and economic ramifications. This is especially true of John D. Schumacher at the National Aeronautics and Space Administration; Sybil Francis, formerly of the Office of Science and Technology Policy; and Robert Hardy, formerly of the National Science Foundation. The ideas that shape this book were first introduced to, and then developed with the help of, colleagues and students at the School of Public Policy at George Mason University 
and Colby College in Waterville, Maine; I am especially indebted to Roger Stough, Kingsley E. Haynes, James R. Fleming, and Leonard Reich for making those opportunities possible. Finally-but by no means least in importance-is the skilled and thoughtful editor who serves even the most experienced writer like a pilot bringing a ship into harbor. Audra J. Wolfe at Rutgers University Press has piloted this book around many a shoal unseen by its author, who is immeasurably in her debt. 



\section{Science and Technology Policy in the United States}


